\title{
Need Analysis Mapping of Entrepreneurship Training of University Student
}

\author{
Sunarni \\ Department of Educational Administration, \\ State University of Malang, Indonesia \\ jengnarni@yahoo.co.id
}

\author{
Wildan Zulkarnain \\ Department of Educational Administration, \\ State University of Malang, Indonesia \\ anzwild@gmail.com
}

\author{
Djum Djum Noor Benty \\ Department of Educational Administration, \\ State University of Malang, Indonesia \\ dj.noor.benty@gmail.com
}

\begin{abstract}
The purposes of this research are: (1) describing the need of entrepreneurship training of university student, and (2) understanding the different need of entrepreneurship training of university students based on their sexes. This research uses quantitative approach with comparative descriptive design. The objects of research are students from Department of Educational Administration, State University of Malang, 2013 and 2014 generation. The results are as follows: (1) almost a half of respondents has entrepreneurship experience and idea which is dominated by fashion and culinary sector; and (2) there are some steps in conducting entrepreneurship training of university students, including: planning (need analysis), implementation, evaluation. The expected output and outcome are that the students are able to settle business. Each step has certain criteria. There are not any differences on the need of joining entrepreneurship training for university students.
\end{abstract}

Keywords: training need analysis, students' entrepreneurship

\section{INTRODUCTION}

Indonesia is a developing country. Ideally Indonesia has turned into developed country as it has so many human resources and natural resources. The number of educated people has improved. University graduated students also significantly increased. There is a problem when this increased number of university graduates couldn't find appropriate job due to the lack of working field availability in formal sector. Many of them do not want to work in non-formal sector. This of course impacts on the increasing of jobless people. Indonesians who work as entrepreneur much less than other ASEAN countries. The Head of Central Official Organization of Indonesian Young Entrepreneur (Badan Pengurus Pusat Himpunan Pengusaha Muda Indonesia / BPP HIPMI), Lahadalia (2016) stated that the number of Indonesian entrepreneur is only $1.5 \%$ of Indonesian total number reaching 252 million. Singapore, Malaysia, Thailand and Vietnam have 7\%, $5 \%, 4.5 \%$, and $3.3 \%$ of entrepreneurs, respectively.

Many students from Department of Educational Administration, State University of Malang expect that they work on formal sector after graduation. A research result conducted by Sunarni (2017) stated: (1) most students are from East Java and graduated from Senior High School, the parents' highest educations are from Senior High School, Parents' occupation is businessmen, students' interest is art, most parents expectation that their children will reach career as public servant (Pegawai Negeri Sipil / PNS); (2) students college after graduation, they have expectation to work in the field of education on the staff of the Ministry of National Education, non-educational field, they have hopes to be an employee of bank; and (3) based on group variable university, sex, and student year, there are similarities and there are differences.

One solution to reduce educated jobless people is through entrepreneurship. Mumtahanah (2016) stated that a university should conduct paradigm change and does not focus on intellectual aspect only. Drucker (1985); Iwantono (2000); and Hendro (2002) suggested that wirausaha is taken from the word wira, meaning courage, struggle and tuff, while usaha means having courage to run business themselves. Kewirausahaan (entrepreneurship) as motivation, ability, attitude, and behavior of a person in handling business or activity in order to search, create, implement new working technique, technology and product by improving efficiency so that it may give better service and gain higher profit.

Sunarni (2016) suggested that Indonesia is surplus of job seeker, especially from university graduates. It needs new troubleshooting to reduce jobless people. One method which can be used is entrepreneurship. University students should be completed with skill, knowledge, tips and trick to make them succeed in the future. University students need career counseling, treatment pattern and motivation so that they can be self-reliance and make career as what they want. Veciana, Aponte and Urbano in their research (2005) showed that entrepreneurship style of university student is positive and good perception in creating new business. However, their appropriate perception is not too positive and only small number of them who have positive willingness in creating new business. The findings of Hattab (2014) suggest positive relationship between entrepreneurship education and intentions and perceived desirability while no relation existed with perceived feasibility or self-efficacy. Johannisson (2016) conducting empirical study in Sweden on business effort suggested that qualified experience and social skill is more important than formal education success. Adapting perspective of entrepreneurship activity, It is useful to provide and facilitate working pattern to identify competency needed in developing entrepreneurship career.

In order that university students get knowledge, entrepreneurship experience and aptitude, higher 
educational institution should conduct seminar training or workshop on entrepreneurship. These activities should be improved that university students have something important to live in community. Therefore, there is a need to conduct mapping on entrepreneurship training need for university students. Gomes (2017) and Kamil (2003) stated that training means any efforts/programs to improve somebody's knowledge and skill on certain job which becomes his responsibility.

\section{METHODS}

This research uses quantitative approach with descriptive comparative technique. Descriptive analysis is used to describe the need of university student's entrepreneurship training consisting of: student's identity, planning, implementing and evaluating. The object of research is students from
Department of Educational Administration, State University of Malang. The number of the object is 101 students consisting of 2013 and 2014 generation. This generation represents student's problem, willingness, expectation and motivation on student's entrepreneurship training need. This generation also got entrepreneurship knowledge on entrepreneurship object study and now they are in process of making thesis and teaching training (Kajian dan Praktik Lapangan / KPL) on semester VII. The data is taken using questionnaire technique. The data is analyzed with cross tabulation descriptive and t-test technique using SPSS for Windows.

\section{RESULT}

Based on data analysis, generation-based respondent, sex, experience and willingness/idea to implement entrepreneurship are shown in Table 1.

Table 1

\begin{tabular}{ccccc}
\multicolumn{5}{c}{ Analysis Result of Respondent Identity } \\
\hline No & Data & Note & Frequency & \% \\
\hline 1 & Respondent Generation & 2013 & 14 & 13.9 \\
& & 2014 & 87 & 86.1 \\
2 & \multirow{2}{*}{ Sex of Respondent } & Male & 28 & 27.7 \\
& & Female & 72 & 71.3 \\
\multirow{2}{*}{3} & \multirow{2}{*}{ Entrepreneurship Experience } & Blank & 1 & 1.0 \\
& & Never & 48 & 47.5 \\
& & Ever & 51 & 50.5 \\
4 & \multirow{2}{*}{ Entrepreneurship willingness } & Blank & 2 & 2.0 \\
& & No willingness & 9 & 8.9 \\
& & Idea & 89 & 88.1 \\
& & Blank & 3 & 3.0 \\
\hline
\end{tabular}

Entrepreneurship experience joined by university students are: fashion, trading, crop, communication, culinary, souvenir, online shop, marketing, education, and publishing. Entrepreneurship idea wanted by university students are: trading, decoration and property; graphical design, photography, publishing; fashion, convection; crop, planting, farming; hand-crafting, souvenir; culinary; technology information, online shop; supermarket, rent car, tourisme; education. Online shop; service sector, supermarket, car rent, tourism; education. Analysis result of entrepreneurship training plan stage is figured out on Table 2.

Table 2

Analysis Result of Entrepreneurship Training Plan Stage

\begin{tabular}{|c|c|c|c|c|}
\hline No & Aspect & Note & Frequency & $\%$ \\
\hline \multirow[t]{3}{*}{1} & Students' Idea about & Agree & 99 & 98.0 \\
\hline & Entrepreneurship & Quite Agree & 2 & 2.0 \\
\hline & & Disagree & 0 & 0 \\
\hline \multirow[t]{3}{*}{2} & Experience in Joining Training & Never & 56 & 55.4 \\
\hline & & Ever & 44 & 43.6 \\
\hline & & No Answer & 1 & 1.0 \\
\hline \multirow[t]{4}{*}{3} & Training Model & Model ATD & 27 & 26.7 \\
\hline & & Model SMA & 12 & 11.9 \\
\hline & & Model TNA & 28 & 27.7 \\
\hline & & Not Knowing & 34 & 33.7 \\
\hline \multirow[t]{5}{*}{4} & Learning Purpose & Affective learning & 9 & 8.9 \\
\hline & & Practice skill / behavioral learning & 69 & 68.3 \\
\hline & & Cognitif learning & 8 & 7,9 \\
\hline & & Others & 9 & 8.9 \\
\hline & & Choosing all & 6 & 5.9 \\
\hline
\end{tabular}

Based on Table 2, analysis result of entrepreneurship training plan stage, most university students agree, $99(98.0 \%)$ if their university conduct entrepreneurship activity intensively. They argue that: (1) it can add their experience/knowledge/selfreliance/creativity/skill; (2) joining entrepreneurship training may reduce educated jobless; and (3) they can create new job-field. The reasons why the students have never joined training are: (1) they aren't interested with the training conducted; (2) they don't have chance; (3) no information about the training; and (4) no asset. Most of the students joined the activity in their senior high school, university, State University of Malang and Brawijaya University, place of field 
college (kuliah kerja nyata / KKN) and Radar Kediri. Most of them joined culinary training, others joined training on café, fashion, broadcasting, crop, communication, hand-craft, marketing, education, news and others. The purposes of joining entrepreneurship training if it is conducted in Department of Educational Administration, State University of Malang are: (1) adding skill and knowledge about entrepreneurship; (2) improving motivation, aptitude in entrepreneurship; and (3) understanding method and techniques for entrepreneurship.

Entrepreneurship training program expected by most of the university students are culinary / snack / restaurant, fashion and convection, and others which relate to cognitive, mental development, entrepreneurship knowledge, skill, entrepreneurship spirit, competency, money management. Other programs expected are crop, property, hand-craft, education and learning training/guidance, marketing / broadcasting, online shop, electronics.

Table 3

Analysis Result of Entrepreneurship Training Implementation Stage

\begin{tabular}{|c|c|c|c|c|}
\hline No & Aspect & Note & Frequency & $\%$ \\
\hline \multirow[t]{16}{*}{1} & \multirow{16}{*}{ Method } & Demonstration & 53 & 52.5 \\
\hline & & Case study & 24 & 24.8 \\
\hline & & Guided teaching & 25 & 24.8 \\
\hline & & Group inquiry & 9 & 8.9 \\
\hline & & Information search & 22 & 21.8 \\
\hline & & Study group & 18 & 17.8 \\
\hline & & Jigsaw learning project & 9 & 8.9 \\
\hline & & Learning tournament & 8 & 7.9 \\
\hline & & Ekperimen & 44 & 43.6 \\
\hline & & Role playing & 26 & 25.7 \\
\hline & & Games and simulations & 29 & 28.7 \\
\hline & & Observation & 24 & 23.8 \\
\hline & & Mental imagery & 13 & 12.9 \\
\hline & & Writing tasks & 5 & 5.0 \\
\hline & & Action learning & 38 & 37.6 \\
\hline & & Others & 1 & 1.0 \\
\hline \multirow[t]{5}{*}{2} & \multirow[t]{5}{*}{ Place for Training } & Campus & 32 & 31.7 \\
\hline & & Aula & 37 & 36.6 \\
\hline & & Hotel & 22 & 21.8 \\
\hline & & Others & 7 & 6.9 \\
\hline & & No answer & 3 & 3.0 \\
\hline \multirow[t]{6}{*}{3} & \multirow{6}{*}{$\begin{array}{l}\text { Appropriate time to conduct } \\
\text { training }\end{array}$} & Process of learning & 33 & 32.7 \\
\hline & & Weekend & 37 & 36.6 \\
\hline & & holidays & 1 & 1.0 \\
\hline & & Semester break & 12 & 11.9 \\
\hline & & Waiting time for graduation & 15 & 14.9 \\
\hline & & No answer & 3 & 3.0 \\
\hline \multirow[t]{12}{*}{4} & \multirow[t]{12}{*}{ Hours number } & 1 hour & 3 & 3.0 \\
\hline & & 2 hours & 31 & 30.7 \\
\hline & & 3 hours & 33 & 32.7 \\
\hline & & 4 hours & 7 & 6.9 \\
\hline & & 5 hours & 7 & 6.9 \\
\hline & & 6 hours & 4 & 4.0 \\
\hline & & 8 hours & 3 & 3.0 \\
\hline & & 12 hours & 2 & 2.0 \\
\hline & & 16 hours & 1 & 1.0 \\
\hline & & 21 hours & 1 & 1.0 \\
\hline & & 24 hours & 1 & 1.0 \\
\hline & & No answer & 8 & 7.8 \\
\hline \multirow[t]{10}{*}{5} & \multirow[t]{10}{*}{ Number of days } & 1 day & 35 & 34.7 \\
\hline & & 2 days & 22 & 21.8 \\
\hline & & 3 days & 17 & 16.8 \\
\hline & & 4 days & 2 & 2.0 \\
\hline & & 5 days & 5 & 5.0 \\
\hline & & 6 days & 1 & 1.0 \\
\hline & & 7 days & 8 & 7.9 \\
\hline & & 8 days & 1 & 1.0 \\
\hline & & 14 days & 1 & 1.0 \\
\hline & & No answer & 9 & 8.9 \\
\hline
\end{tabular}

Analysis result of entrepreneurship training stage, entrepreneurship training stage offered by students are many. Some focused on workshop and training only and others focused on practice to begin business and problem solving faced by students. The stages offered are: (1) planning consisting of deciding theme, official forming, participants, time, facilities, subject material, method, evaluation and socialization; (2) the implementation stage in the form of seminar / workshop / training: opening, detection kind of entrepreneurship, entrepreneurship materials, giving examples from successful businessman, practice (creating business center). Implementation stage involves an exhibition of entrepreneurship types; and 
3) activity evaluation stage. The outcome that the students will have their own business.

Entrepreneurship training materials include: (1) theory of entrepreneurship; (2) entrepreneurship management (entrepreneurship stages); (3) leadership; (4) decision making; (5) accounting; and (6) communication. Entrepreneurship strategies expected are: (1) electronics media; video, film, power-point material; and (2) non-electronic media: stand/windows/example/real product, successful businessman, module/handbook, pamphlet, action tool and action learning project. Human resources: mentor and participant. Facilities needed are: (1) training module/material, tool for action; (2) building/aula (AC, table, chair, microphone, tape recorder, banner, doorprize, windows for product exhibition, camera, brosure, LCD, laptop; (3) writing tools; (4) certificate; and (5) consumption \& snack. Training method, appropriate place, time, total hours and days expected by students are figured out on Table 3.

Analysis result of entrepreneurship training evaluation stage. Based on the analysis result of this stage, outcome or skill expected by students are: (1) getting knowledge about entrepreneurship on cognitive, affective and pshycomotoric aspects (skill); and (2) having skill in: (a) cognitive: innovation, chance reading, competitive business, money management, strategy/entrepreneurship technique, (b) affective: mental on entrepreneurship, self-reliance, aptitude and motivation, (c) psychomotoric: communication, problem solving, marketing/promotion, networking, asset grabbing, business management; and (4) being able to run business. According to students, on evaluation stage, respondents' answer are presented on Table 4.

Table 4

Analysis Result of Entrepreneurship Training Evaluation Stage

\begin{tabular}{|c|c|c|c|c|}
\hline No & Aspect & Note & Frequency & $\%$ \\
\hline \multirow[t]{5}{*}{1} & \multirow[t]{5}{*}{ Pretest } & No answer & 3 & 3,0 \\
\hline & & Not needed & 2 & 2,0 \\
\hline & & Little bit needed & 15 & 14,9 \\
\hline & & Needed & 31 & 30,7 \\
\hline & & Badly needed & 50 & 49,5 \\
\hline \multirow[t]{5}{*}{2} & \multirow{5}{*}{$\begin{array}{l}\text { Detection of entrepreneurship } \\
\text { spirit }\end{array}$} & No answer & 3 & 3,0 \\
\hline & & Not needed & 0 & 0,0 \\
\hline & & Little bit needed & 5 & 5,0 \\
\hline & & Needed & 27 & 26,7 \\
\hline & & Badly needed & 66 & 65,3 \\
\hline \multirow[t]{5}{*}{3} & \multirow[t]{5}{*}{ Post-test } & No answer & 4 & 4,0 \\
\hline & & Not needed & 2 & 2,0 \\
\hline & & Little bit needed & 7 & 6,9 \\
\hline & & Needed & 29 & 28,7 \\
\hline & & Badly needed & 59 & 58,4 \\
\hline \multirow[t]{5}{*}{4} & \multirow[t]{5}{*}{ Evaluation of training program } & No answer & 3 & 3,0 \\
\hline & & Not needed & 2 & 2,0 \\
\hline & & Little bit needed & 5 & 5,0 \\
\hline & & Needed & 34 & 33,7 \\
\hline & & Badly needed & 57 & 56,4 \\
\hline \multirow[t]{5}{*}{5} & \multirow[t]{5}{*}{ Evaluation category } & No answer & 3 & 3,0 \\
\hline & & Not needed & 1 & 1,0 \\
\hline & & Little bit needed & 3 & 3,0 \\
\hline & & Needed & 20 & 19,8 \\
\hline & & Badly needed & 74 & 73,3 \\
\hline
\end{tabular}

Table 5

Comparative Analysis Result based on Generation and Sex

\begin{tabular}{clccc}
\hline \multicolumn{1}{c}{ Aspect } & F & $\begin{array}{c}\text { Sig (2-tailed) } \\
\text { Equal variance not assumed }\end{array}$ & Note \\
\hline 1 & Entrepreneurship experience & 0.824 & 0.906 & $\mathrm{H}$ valid \\
2 & Entrepreneurship will/idea & 1.092 & 0.574 & H0 valid \\
3 & University idea in conducting & 1.928 & 0.573 & H0 valid \\
& entrepreneurship activity & & & H0 valid \\
4 & Experience joining training & 0.071 & 0.334 & H0 valid \\
5 & Students' purpose joining training & 0.159 & 0.066 & H0 valid \\
6 & Training model & 0.486 & 0.619 & H0 valid \\
7 & Comfortable place & 0.004 & 0.057 & H0 valid \\
8 & Appropriate time & 4.307 & 0.702 & H0 valid \\
9 & Number of hours & 13.752 & 0.212 & H0 valid \\
10 & Number of days & 0.709 & 0.217 & H0 valid \\
11 & Evaluation & 0.134 & 0.806 & \\
\hline
\end{tabular}

Comparative analysis result differentiates students' experience, idea, need on entrepreneurship training based on generation and sex as presented on Table 5. Based on analysis result of comparative testdata based on sex, it is stated that Ho is valid, meaning that experience on entrepreneurship, entrepreneurship idea, experience on joining entrepreneurship training, purpose, model, place, time number of hours, number of days and evaluation are not different (similar) between male and female in joining entrepreneurship training for students. 


\section{RESULTS AND DISCUSSION}

Based on analysis result of respondent identity in which researcher took respondent from 2 generations, 2013 generation, mostly of whom graduate in second semester of 2016/2017, and 2014 generation, most of whom is taking PPL (Field Experience Practice). These two generations have finished entrepreneurship subject matter and had knowledge on entrepreneurship.

Female respondents dominate more than male respondents. From entrepreneurship experience, many respondents stated that they have experience more than those who have never joined entrepreneurship training. Almost all students have idea and willingness to conduct entrepreneurship. Fashion, culinary and communication dominate more on entrepreneurship experience for students. From all entrepreneurship idea, students expect to run entrepreneurship in culinary and fashion.

Sunarni, et al (2016) stated that the results are: (1) perception of college students to department is good; (2) expectation of college student is very high; and (3) based on university and gender group variable, perception and expectation of students there are similarities. However based on the academic year, college student's expectation is not the same. Based on university and gender group variable, perception and expectation of students there are similarities. However based on the academic year, expectation of students' college is not the same. Students need to get many experiences to run entrepreneurship. Mumtahanah (2016) suggested that early age education based on entrepreneurship becomes beginning foundation that will create tuff generation. When this age is filled with entrepreneurship character, then the future generation will have tuff mental in facing challenge.

Experience in joining entrepreneurship training shows no different between those who has joined training and those who hasn't joined yet. Most students do not know much about model of training. In training purpose aspect, most students choose practice skill/behavioral learning. Silberman (1998) stated that training purposes had by participants are: (1) to get added value of new system (affective learning); (2) fulfillment and process type (behavioral learning); and (3) deciding the right form of the fill used (cognitive learning).

Based on Table 3, method expected at the time of entrepreneurship training is dominated by demonstration, experiment and action learning method. Susilaningsih (2016) stated that research result on method to improve students' thinking and acting are: (1) integrating entrpreneurship into courses audio development learning throught models of advance organizer; (2) implement a model advance organizer to increase student confidence in thinking and acting in entrepreneurship in the corridor courses audio learning development; and (3) this research was conducted in order to empower potential and resources existing learning at the Department of Educational Technology, State University of Malang, including server, workstations and LAN system using the SAPROL. Nasr \& Boujelbene (2014) the findings show that programs offered by entrepreneurship's master have a positive impact on entrepreneurial intention and profiles of participants. Then, entrepreneurship's master alumni how have find a job have transferred what they have learned on their works.

Training place which is used mostly is in aula. The second is in campus, and the last in hotel (almost in balance). Appropriate time expected by students are on weekend, the second is on the learning process time and waiting time for graduation. Number of hours to conduct training is about 2-3 hours in 1-2 days. Based on Table 4, it is stated that pretest is badly needed. Before giving training material to students, developing team has tool for detecting entrepreneurship spirit. This tool is the gift from Department of Education Management, Education Science Faculty of Surabaya State University. It will be used to detect entrepreneurship spirit on the beginning of activity before training material given. Most respondents told that they badly needed the tool. On post-test aspect, most respondents stated that they need the test much. On the final activity, most respondents stated that is needed much and it needs training program evaluation to be implemented. Based on the whole evaluation category, respondents stated that it is needed.

From the research it is found that there is no difference between male and female in joining entrepreneurship training. According to Alma (2007) there is difference between male and female in new entrepreneurship aspect: (1) businesswoman is motivated to open business because they want to get achievement and actually they are bored with the previous job. They feel unfree in showing their skill and developing aptitude had; (2) businessman have more chance in getting business asset, while businesswoman get asset from saving and self-credit. Businesswoman feels more difficult in getting credit from bank than businessman; (3) most business woman is more tolerance, flexible, realistic, and creative, eager and energetic, and has medium level of selfconfidence. Most men has higher self-confidence than woman; (4) the age for men to begin running business is 25-35 years old, while woman begins business on 35-45 years old; (5) relatives who support woman in running business is their family, husband, woman organization and their groups; and (6) business types run by businessman are many, while most businesswoman run on service, education, consultant and public relation business.

Kusumawati (2017) stated that students of department of educational, State University of Malang have five personalities, psychological capital and intensity in running business. Most of them have high category in that personality. There is positive and significant correlation between big five personalities and psychological capital with entrepreneurship intensity.

\section{CONCLUSION}

From the research, it can be concluded that: (1) most respondents have experience and idea of business dominated by fashion and culinary sectors; and (2) in conducting entrepreneurship training there are some 
stages (need analysis), implementation stage, evaluation, output expected and outcome, students' capability in running business, and 3 ) there is no difference between male and female in their need to join entrepreneurship training.

Suggestions given are: (1) students should add their knowledge and skill on entrepreneurship as an asset after graduating; and (2) lecturer, head of department and university should give information, motivation, knowledge, support, facilities and improve students' competence in entrepreneurship.

\section{REFERENCES}

[1] Alma, B. 2007. Kewirausahaan untuk Mahasiswa dan Umum. Bandung: Alfabeta.

[2] Drucker, P. F. 1985. Innovation and Entrepreneurship: Practice and Principle. New York: Pearson.

[3] Gomes, F.C. 2003. Manajemen Sumber Daya Manusia. Yogyakarta: Andi Offset.

[4] Hattab, H. W. 2014. Impact of Entrepreneurship Education on Entrepreneurial Intentions of University Students in Egypt. The Journal of Entrepreneurship, 23(1), 1-18.

[5] Hendro. 2011. Dasar-dasar Kewirausahaan (Panduan bagi Mahasiswa untuk Mengenal, Memahami Dunia Bisnis). Jakarta: Erlangga.

[6] Iwantono, S. 2002. Kiat Sukses Berwirausaha. Jakarta: Gramedia.

[7] Johannisson, B. 2006. University Training for Entrepreneurship: Swedish Approaches. Entrepreneurship \& Regional Development An International Journal, 3(1), 67-82.

[8] Kamil, M. 2003. Model-Model Pelatihan. Retrieved December 2, 2016, from http://file.upi.edu/Direktori/ fip/jur._pend._luar_sekolah/196111091987031001mustofa_kamil/Model-model_pelatihan.pdf.

[9] Kusumawati, E. 2017. Hubungan Big Five Personality dan Psychological Capital dengan Intensitas Berwirausaha pada Mahasiswa Jurusan Administrasi Pendidikan Universitas Negeri Malang. Thesis. Malang: State University of Malang.

[10] Lahadalia, B. 2016. Jumlah Pengusaha di Indonesia Baru 1,5\% dari Total Penduduk. Retrieved December 20, 2016, from http://www.suara.com.

[11] Mumtahanah, I. A. 2016. Pendidikan Anak Usia Dini Berkarakter Entrepreneurship. National Seminar on Entrepreneurship dalam Perspektif PAUD, October 29, 2016.

[12] Nasr, K. B. \& Boujelbene, Y. 2014. Assessing the Impact of Entrepreneurship Education. Procedia Social and Behavioral Sciences, 109(8), 712-715, Retrieved December 22, 2016, from http://www.sciencedirect.com/science/article.

[13] Silberman, M. 1998. Active Training (A Handbook of Techniques, Designs, case Examples, and Tips). San Francisco: Jossey-Bass.

[14] Sunarni. 2016. Jiwa Entrepreneurship dan Faktorfaktor yang Mempengaruhi Pemilihan Karir Mahasiswa. National Seminar on Entrepreneurship dalam Perspektif PAUD, October 29, 2016.

[15] Sunarni. 2017. The Mapping of University Student's Background, expectation, and Entrepreneurship View on Future Career. International Research Based Education Journal, 1(1), 69-76.

[16] Sunarni, Zulkarnain, W., Roesminingsih, E., dan Sulasminten. 2016. Mapping of Student College Perception and Expectation on Future Career
International Conference on Education and Training, Faculty of Education, State University of Malang, $2^{\text {nd }}$ ICET, 4-6 November.

[17] Susilaningsih. 2016. Method Content Lectures Strengthening Entrepreneurship in Thinking and Acting. International Conference on Education and Training, Faculty of Education, State University of Malang, 2nd ICET, 4-6 November.

[18] Veciana, J. M., Aponte, M., and Urbano, D. 2005. University Students' Attitudes Towards Entrepreneurship: A Two Countries Comparison. The International Entrepreneurship and Management Journal, 1(2), 165-182. 